a mutation at exon 11 [7], and another patient responsive to $C D$ was reported [10]. More cases need to be studied.

Keywords: Hairy cell leukemia, $B R A F$

Anahtar Sözcükler: Saçlı hücreli lösemi, BRAF

Conflict of Interest: The authors declare no conflicts of interests.

\section{Authorship Contributions}

Design: A.G., V.S., M.B.; Data Collection or Processing: D.R.; Writing: A.G., F.B.

\section{Acknowledgments}

The authors thank the Hairy Cell Leukemia Foundation for support for patients and for arranging the annual experts meeting in order to share diagnostic and therapeutic information.

\section{HAIRY CELL LEUKEMIA}

This case was presented in part at the 2014 Hairy Cell Leukemia Foundation Annual Meeting in Houston, TX, USA.

\section{References}

1. Grever MR, Abdel-Wahab O, Andritsos LA, Banerji V, Barrientos J, Blachly JS, Call TG, Catovsky D, Dearden C, Demeter J, Else M, Forconi F, Gozzetti $A$, Ho AD, Johnston JB, Jones J, Juliusson G, Kraut E, Kreitman RJ, Larratt L, Lauria F, Lozanski G, Montserrat E, Parikh SA, Park JH, Polliack A, Quest GR, Rai KR, Ravandi F, Robak T, Saven A, Seymour JF, Tadmor T, Tallman MS, Tam C, Tiacci E, Troussard X, Zent CS, Zenz T, Zinzani PL, Falini B. Consensus guidelines for the diagnosis and management of patients with classic hairy cell leukemia. Blood 2017;129:553-560.
2. Tiacci $E$, Trifonov V, Schiavoni G, Holmes A, Kern W, Martelli MP, Pucciarini A, Bigerna B, Pacini R, Wells VA, Sportoletti P, Pettirossi V, Mannucci R, Elliott O, Liso A, Ambrosetti A, Pulsoni A, Forconi F, Trentin L, Semenzato G, Inghirami G, Capponi M, Di Raimondo F, Patti C, Arcaini L, Musto P, Pileri S, Haferlach C, Schnittger S, Pizzolo G, Foà R, Farinelli L, Haferlach T, Pasqualucci L, Rabadan R, Falini B. BRAF mutations in hairy-cell leukemia. N Engl J Med 2011;364:2305-2315.

3. Tiacci E, Schiavoni G, Martelli MP, Boveri E, Pacini R, Tabarrini A, Zibellini S, Santi A, Pettirossi V, Fortini E, Ascani S, Arcaini L, Inghirami G, Paulli M, Falini B . Constant activation of the RAF-MEK-ERK pathway as a diagnostic and therapeutic target in hairy cell leukemia. Haematologica 2013;98:635639 .

4. Xi L, Arons $E$, Navarro $W$, Calvo KR, Stetler-Stevenson $M$, Raffeld $M$, Kreitman RJ. Both variant and IGHV4-34-expressing hairy cell leukemia lack the BRAF V600E mutation. Blood 2012;119:3330-3332.

5. Schnittger $S$, Bacher U, Haferlach $T$, Wendland $N$, Ulke M, Dicker $F$, Grossmann V, Haferlach C, Kern W. Development and validation of a realtime quantification assay to detect and monitor BRAFV600E mutations in hairy cell leukemia. Blood 2012;119:3151-3154.

6. Langabeer SE, O'Brien D, McElligott AM, Lavin M, Browne PV. BRAF V600Enegative hairy cell leukaemia. Case Rep Hematol 2013;2013:513049.

7. Tschernitz $\mathrm{S}$, Flossbach $L$, Bonengel $M$, Roth $S$, Rosenwald $A$, Geissinger E. Alternative BRAF mutations in BRAF V600E-negative hairy cell leukaemias. Brit J Haematol 2014;165:529-533.

8. Waterfall JJ, Arons E, Walker RL, Pineda M, Roth L, Killian JK, Abaan OD, Davis SR, Kreitman RJ, Meltzer PS. High prevalence of MAP2K1 mutations in variant and IGHV4-34 expressing hairy-cell leukemia. Nat Genet 2014;46:810.

9. Maitre $E$, Bertrand $P$, Maingonnat C, Viailly PJ, Wiber M, Naguib D, Salaün V, Cornet E, Damaj G, Sola B, Jardin F, Troussard X. New generation sequencing of targeted genes in the classical and the variant form of hairy cell leukemia highlights mutations in epigenetic regulation genes. Oncotarget 2018;9:28866-28876.

10. Hossain A, Rafei H, Jariwala A, El-Shami K. A rare breed: Wild-type braf and ighv expression in a 29 year old lady with classical hairy cell leukemia. Leuk Res Rep 2017;7:20-22.

\title{
CD9 Is a Very Helpful Marker for Discriminating AML-M3 from HLA-DR-Negative Non-M3 AML
}

CD9 AML-M3 ve HLA-DR-Negatif M3 Dışı AML'nin Ayırt Edilmesinde Çok Yararlı Bir

\section{Belirteçtir}

(D) Esmaeil Shahabi Satlsar1,2, (D) Mohammad Mosleh33, (D) Mahdieh Mehrpouri4

1 Guilan University of Medical Sciences,School of Paramedical Sciences, Clinical Laboratory Sciences Department, Rasht, Iran

2Thakhte Tavous Pathobiology Laboratory, Flow Cytometry Department, Tehran, Iran

${ }^{3}$ Shahid Beheshti University of Medical Sciences, Hematology and Blood Banking Department, School of Paramedical Sciences, Tehran, Iran

${ }^{4}$ Alborz University of Medical Sciences, School of Paramedical Sciences Clinical Laboratory Sciences Department, Karaj, Iran 


\section{To the Editor,}

CD9 is a cell-surface marker whose carcinogenic properties have been proven in several solid tumors. Previous studies reported that the blast cells of both B-cell acute lymphoblastic leukemia (ALL) and acute myeloid leukemia (AML), as well as normal B-cell precursors (hematogones), express CD9 $[1,2,3]$. Acute promyelocytic leukemia (APL) is a highly aggressive type of AML with an increased risk of death due to hemorrhage, and flow cytometry provides an accessible and useful tool for the rapid diagnosis of APL. Promyelocytes in APL are characterized by negative expression of HLA-DR, CD11b, and CD34 and they are often positive for cMPO (bright), CD13, CD33, CD34 (dim), CD64, and CD117 (dim to moderate). Another subtype of AML known as HLA-DR-negative non-M3 AML also lacks the expression of HLA-DR and CD34 $[4,5]$. Differential diagnosis of APL from HLADR-negative non-M3 AML cannot be based on morphology and lack of HLA-DR antigen expression; rather, it requires molecular confirmation of PML-RARA using cytogenetic analysis, which leads to delayed diagnosis. In our previous study evaluating the expression of CD9 in AML cases [6], we showed differences in the expression of CD9 between blasts of APL and HLA-DRnegative non-M3 AML. With respect to the interesting results of the previous study, we decided to continue evaluating this marker in patients with APL and HLA-DR-negative non-M3 AML. Accordingly, we evaluated CD9 expression in 101 patients with APL and 94 patients with HLA-DR-negative non-APL using flow cytometry; moreover, molecular evaluation for PML-RARA was performed for all studied patients for confirming the suspected diagnosis of APL.
Flow cytometric analysis was performed using a Beckman Coulter Cytomics FC 500 flow cytometer with MXP software. Bone marrow and/or peripheral blood samples were taken from the patients between March 2015 and January 2020. The following conjugated monoclonal antibodies were used in four-color combinations: CD9 (FITC-Coulter), HLA-DR (PEDako), HLA-DR (PE-Immunostep), CD13 (Percp/Cy5-BD), CD33 (APC-Coulter), CD64 (PE-Dako), CD117 (PE-Coulter), CD34 (PE$\mathrm{BD})$, and CD45 (Percp-Immunostep). Resulting data showed that both APL patients and HLA-DR-negative non-APL patients expressed the CD9 marker, although each group had a distinct pattern of expression. Consistent with that finding, our data revealed that all APL patients (100\%) showed homogeneous and moderate or bright expression of CD9, similar to the pattern of CD33 expression. Conversely, in HLA-DR-negative non-APL patients, CD9 expression was detected in 59 of 94 (62.7\%) of cases, with a heterogeneous pattern and dim to moderate expression, which is a completely different pattern from that seen in cases of APL (Figure 1).

The timely diagnosis of APL continues to be challenging despite advancements in medical diagnostics in many countries of the world. Furthermore, the abnormal morphology of promyelocytes, especially in the hypogranular variants [7], and the expression of CD11b can lead to diagnostic errors in some cases.

The most straightforward explanation of our results is that expression patterns of CD9, along with other myeloid markers such as $C D 13, C D 33$, and $C D 64$, can be helpful in the precise
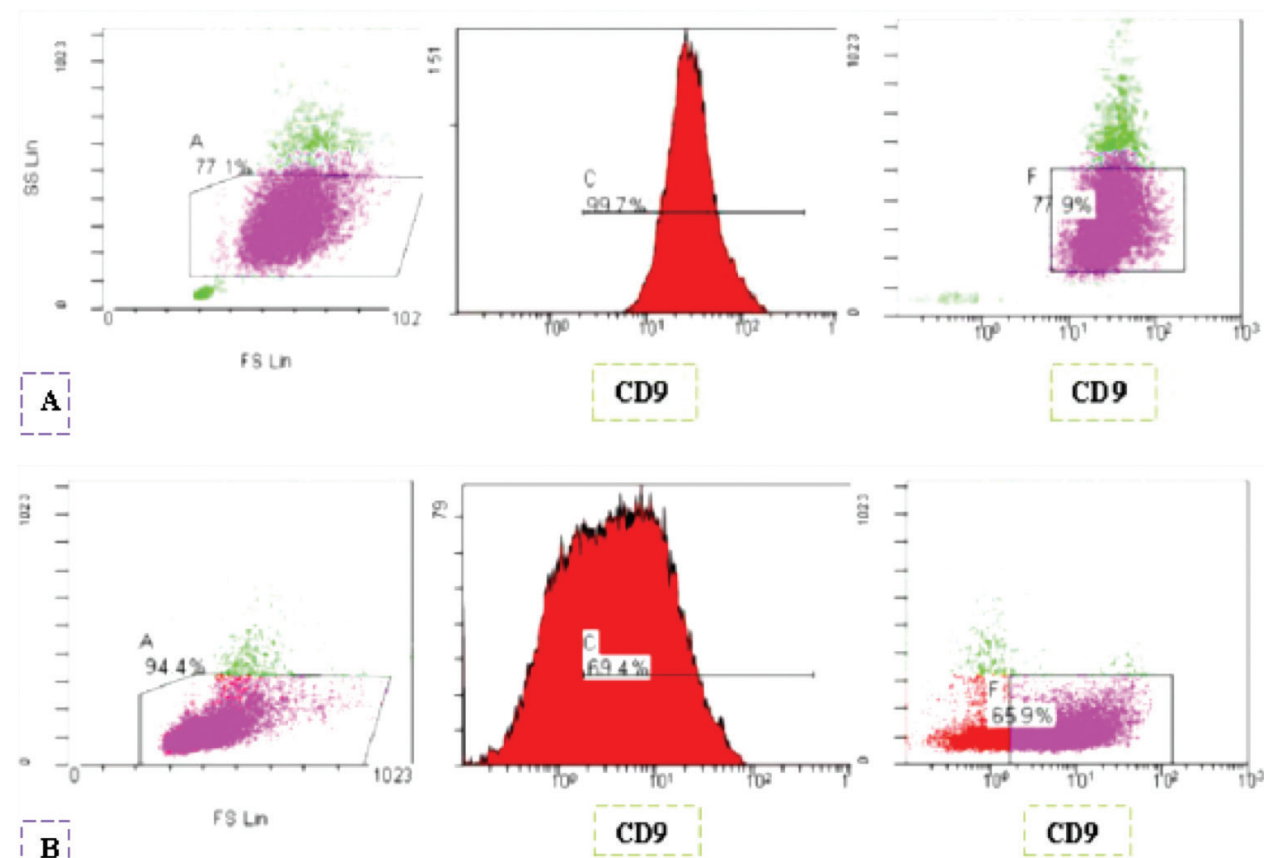

Figure 1. Differences in CD9 expression patterns in APL and HLA-DR-negative non-APL: A) APL blasts show homogeneous and moderate to bright expression, B) HLA-DR-negative non-APL cases have dim to moderate and heterogeneous expression. 
differential diagnosis of patients with APL from patients with HLA-DR-negative non-APL.

Keywords: AML-M3, CD9, Flow cytometry, HLA-DR-negative AML

Anahtar Kelimeler: AML-M3, CD9, Akım sitometri, HLA-DR negative AML

\section{Authorship Contributions}

Design: E.S.S., M.M., M.o.M., Data collection: E.S.S., Analysis: M.M., Writing: M.o.M.

Conflict of Interest: The authors declare no conflict of interest.

\section{References}

1. Touzet L, Dumezy F, Roumier C, Berthon C, Bories C, Quesnel B, Preudhomme C, Boyer T. CD9 in acute myeloid leukemia: prognostic role and usefulness to target leukemic stem cells. Cancer Med 2019;8:1279-1288.
2. Allahbakhshian M, Shahabi Satlsar E, Mohseni A, Mosleh M, Mehrpouri M, Agaeipour M, Mohammadi MH, Gholampour R, Jadali F. Use of four-color flow cytometric assay for discrimination of hematogone from lymphoblast: critical issue for MRD assessment in B-ALL patients. Iran J Ped Hematol Oncol 2020;10:17-27.

3. Yamazaki $\mathrm{H}, \mathrm{Xu} \mathrm{CW}$, Naito $\mathrm{M}$, Nishida $\mathrm{H}, \mathrm{Okamoto} \mathrm{T}$, Ghani Fl, Iwata $\mathrm{S}$, Inukai T, Sugita K, Morimoto C. Regulation of cancer stem cell properties by CD9 in human B-acute lymphoblastic leukemia. Biochem Biophys Res Commun 2011;409:14-21.

4. Adams J, Nassiri M. Acute promyelocytic leukemia: a review and discussion of variant translocations. Arch Pathol Lab Med 2014;139:1308-1313.

5. Wetzler M, McElwain BK, Stewart CC, Blumenson L, Mortazavi A, Ford LA, Slack JL, Barcos M, Ferrone S, Baer MR. HLA-DR antigen-negative acute myeloid leukemia. Leukemia 2003;17:707-715.

6. Mosleh M, Mehrpouri M, Ghaffari S, Saei Z, Agaeipoor M, Jadali F, Satlsar ES, Gholampour R. Report of a new six-panel flow cytometry marker for early differential diagnosis of APL from HLADR negative non-APL leukemia. Scand J Clin Lab Invest 2020;80:87-92.

7. Akhtar K, Ahmad S, Shervani RK. Acute promyelocytic leukemia, hypogranular variant: a rare presentation. Clin Pract 2011;1:e11.

\section{Comment: In Response to "CD9 Is a Very Helpful Marker for Discriminating AML-M3 from HLA-DR-Negative Non-M3 AML"}

\section{Yorum: "CD9 AML-M3'ü HLA-DR Negatif M3 Dışı AML'den Ayırt Etmede Çok Faydalı Bir Belirteçtir}

(D) Smeeta Gajendra

Laboratory Oncology Unit, Dr. B.R.A. IRCH, AIIMS, New Delhi, India

\section{To the Editor,}

I read the letter "CD9 Is a Very Helpful Marker for Discriminating AML-M3 from HLA-DR-Negative Non-M3 AML" by Satlsar et al. [1], published in this journal. The manuscript is well written with description of a very informative topic of expression pattern of CD9 in acute promyelocytic leukemia (APL). There is bright homogeneous expression of CD9 in APL, whereas the expression is dimmer and heterogeneous in non-APL cases. CD9 is a tetraspanin molecule that is expressed on a wide variety of hematopoietic cells as precursor B cell, megakaryocytes, and certain acute myeloid leukemias. CD9 is associated with poor prognosis in ALL and good prognosis in AML cases. CD9 can be used as a biomarker and can be considered as therapeutic target. APL has distinct morphologic, biologic, and clinical features. The diagnosis is predominantly based on morphology which is characterized by presence of abnormal promyelocytes with bilobed nuclei and frequent Auer rods and a cytogenetic/molecular hallmark of $\mathrm{t}(15 ; 17)(\mathrm{q} 22 ; \mathrm{q} 21) \quad P M L-R A R A$. Multiparameter flow cytometry evolved as a rapid diagnostic tool along with morphology for early detection and immediate starting of therapy to avoid life threatening complications. On flow cytometry, these abnormal promyelocytes have a teardrop pattern with high SCC in CD45SSC plots due to prominent granulations which mimic the position of granulocytes but lack CD15, CD16, and CD11c, which 